\title{
Development of Evaluation Methodology for Carbon Dioxide Emissions in Production Processes
}

\author{
Evija Grege-Staltmane, JSC "Latvijas valsts mezi"
}

\begin{abstract}
Present study identifies the main $\mathrm{CO}_{2}$ emissions in production processes for forest management company JSC "Latvijas valsts mezi". The goal of calculations was to precisely determine $\mathrm{CO}_{2}$ emissions for the company and approximately for outsourcing. It was found that the largest amount of JSC "Latvijas valsts mezi" company's outsourcing $\mathrm{CO}_{2}$ emissions in production processes are for forest infrastructure development, supply of wood assortment and roundwood harvesting. The major amount of JSC "Latvijas valsts mezi" company's $\mathrm{CO}_{2}$ emissions is in the Forest Management unit and in the Seeds and Plants unit.
\end{abstract}

Keywords - carbon footprint, $\mathrm{CO}_{2}$ emissions, forestry management, production processes.

\section{INTRODUCTION}

In terms of climate, forests act as carbon sinks because of photosynthesis, trees remove $\mathrm{CO}_{2}$ from the atmosphere by an accumulation of carbon and releasing oxygen. In a sustainably managed forest, carbon storage never stops, as new trees replace harvested ones. It is possible to find many studies [1,2] about carbon storage in forest and wood products, while the studies about $\mathrm{CO}_{2}$ emissions in forestry are very few, except emissions from forest bioenergy production are widely described [3]

The term "carbon footprint" has appeared in the last ten years. It is a measure of the greenhouse gas emissions associated with an activity, group of activities or a product [4].

JSC "Latvijas valsts mezi" (hereinafter - LVM) pursues state interests in forestry by sustaining and increasing the forest value, while gaining maximum possible value from forest management in Latvia. Along with timber as its major product, the company also develops other lines of business, suchas the production of genetically improved forest tree seeds and plants, hunting and game management, and recreational services. LVM provides its customers with sawlogs, veneer logs, industrial wood, pulpwood, and fuelwood. LVM supplies fuel chips to produce green energy in Latvia and abroad. LVM offers sand, gravel, as well as peat for excavation.

One of the company's strategic objectives is to reduce the impact of its economic activities on the environment. Carbon dioxide $\left(\mathrm{CO}_{2}\right)$ emissions generated from forest operations is one of the factors which impacts environment.

The company started research of forestry management influence on $\mathrm{CO}_{2}$ emissions and removals in trees, soil, wooden products, but $\mathrm{CO}_{2}$ emissions are also from the process of forest management: the consumption of fuel and electricity, heating offices and so on. Therefore, the company has set a goal - to develop the evaluation methodology for $\mathrm{CO}_{2}$ emissions in production processes also known as $" \mathrm{CO}_{2}$ footprint".

\section{METHODOLOGY}

The methodological approach which was described in the Greenhouse Gas Protocol [5] has been adapted to LVM specific nature in $\mathrm{CO}_{2}$ emissions determination. The emissions obtained from the company activities have been assessed. The complex of the method consists of four stages:

1. Establishment of the assessment boundaries;

2. Choosing a base year;

3. Collection of data;

4. Calculation of emissions using appropriate local or international documents where emission factors are determined.

The establishment of assessment boundaries means to clearly determine what would be included in the calculations and how detailed the calculation would be, for example, for the whole organization or just one unit. The three scopes provide an accounting framework according to the above mentioned standard:

Scope 1: Direct greenhouse gas emissions:

- Fuel combustion;

- Fugitive \& process emissions.

Scope 2: Electricity indirect greenhouse gas emissions:

- Purchased electricity, heat or steam for own use.

Scope 3: Other indirect greenhouse gas emissions:

- Employee business travel;

- Contractor owned vehicles;

- Outsourced activities;

- Production of purchased materials;

- Waste disposal.

Figure 1 completely covers scopes 1 and 2 in LVM calculations for 2011 as well as part of scope 3 (employee business travel, transport services and emissions from receiving services).

The company also includes related companies such as Ltd. "Jaunmoku pils" (100\%) and Ltd. "Meža un koksnes produktu pētniecības un attīstības institūts" (44.22\%), however these have not been included in GHG calculations. 


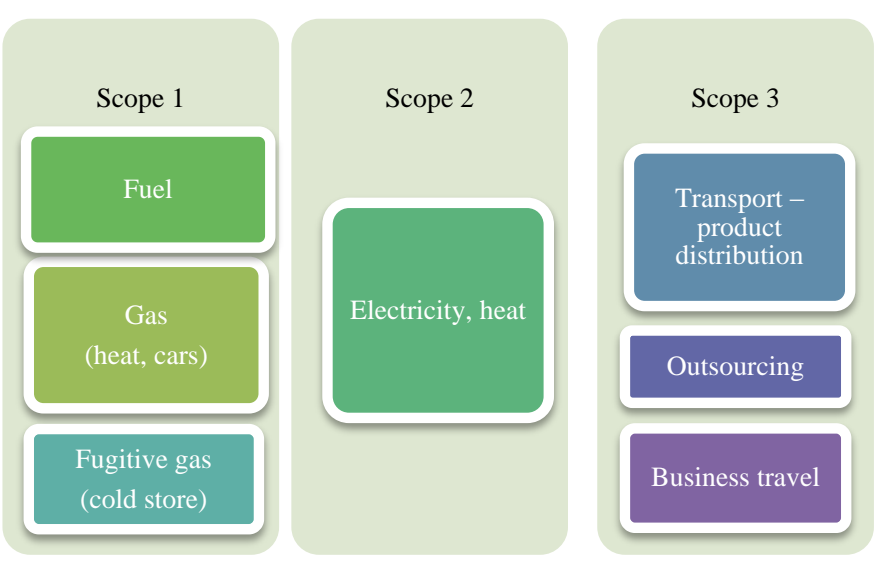

Fig.1. LVM assessment boundaries in $\mathrm{CO}_{2}$ footprint determination

The goal of calculations is to precisely determine $\mathrm{CO}_{2}$ emissions for LVM and approximately for outsourcing mainly estimated fuel consumption for 2011. LVM company emissions were also calculated for the years 2010 and 2009.

The company has chosen to make the calculations for eliminated main product and services directions, forestry management structuring into five sections:

- Seeds and plants;

- Management of mineral resources;

- Real estate;

- Forest management:

○ Roundwood harvesting.

- Supply of fuel chips;

○ Supply of wood assortment;

- Silviculture;

- Forest infrastructure development;

- Services in recreation and hunting.

Special spread sheets were created to calculate emissions for the above mentioned units.

All emissions for each calculation unit are divided in two parts - the company's emissions and outsourcing emissions (see Fig. 2). The Seeds and Plants unit has no outsourcing emissions. Outsourcing emissions mainly consist of fuel combustion. LVM has $96 \%$ of outsourcing emissions and $4 \%$ of their own GHG emissions.
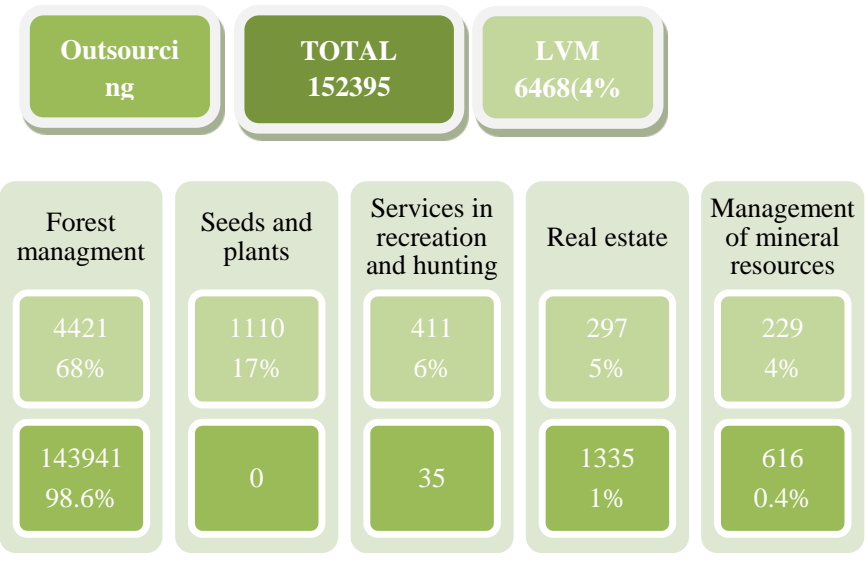

Fig. 2. LVM and outsourcing $\mathrm{CO}_{2}$ emissions in tonnes in the year 2011
Other greenhouse gases are not assessed separately in these calculations for example $\mathrm{N}_{2} \mathrm{O}, \mathrm{CH}_{4}, \mathrm{HFC}$ etc. is the calculations concentrated only on $\mathrm{CO}_{2}$ emissions and if there were such other gases, they were converted into $\mathrm{CO} 2$ equivalents already in an emission factor.

Data on consumed resources were collected from invoices in LVM, but the emissions from services were retrieved from contracts or internal calculations for the year 2011. Fuel costs are estimated from the contracts according to service prices, which are set in the contracts. These are fuel cost impact coefficients. LVM pays a set price per service and an estimate on what percentage of that price is delineated for fuel costs. Those fuel costs are divided by the average fuel price that year, to get the litres. In cases where the kind of fuel is not known, it is assumed that diesel and gasoline have been used in similar proportions, i.e. $50 \%$ of each. It was assumed that the diesel consumption for a harvester of 0.96 litres $/ \mathrm{m}^{3}$ for clear cut, 1.37 litres/ $\mathrm{m}^{3}$ for sanitary cut, 1.71 litres $/ \mathrm{m}^{3}$ for thinning and for a forwarder of 1.21 litres/ $\mathrm{m}^{3}$ for clear cut, 1.42 litres $/ \mathrm{m}^{3}$ for sanitary cut, 1.82 litres $/ \mathrm{m}^{3}$ for thinning. The average fuel consumption is assumed as $521 / 100 \mathrm{~km}$ for timber deliveries.

The volumes and the amount of money for outsourcing service providers were taken from the budgets of the LVM (Microstrategy) for 2011. Data from the Central Statistical Bureau of Latvia were used in the estimation of average fuel costs. (1).

The $\mathrm{CO}_{2}$ emissions were calculated as indicated in equation

$$
E_{c o}=D \cdot e
$$

Selected data for the calculation (D) are summarized in the corresponding units and multiplied by an emission factor (e), resulting in $\mathrm{CO}_{2}$ emissions $\left(\mathrm{E}_{\mathrm{co}}\right)$. The emission factor represents how much $\mathrm{CO}_{2}$ is emitted into the atmosphere by consuming 1 unit of energy or material. In this study six emission factors were represented for electricity, gas, freon and fuel. The two fuel emission factors were most used for diesel $-2.63 \mathrm{CO}_{2}$ eqv./liter and for gasoline - $2.315 \mathrm{CO}_{2}$ eqv./liter in these calculations. The emission factors selected from recognised original sources such as 2011 Guidelines to Defra DECC's and GHG Conversion Factors for Company reporting or local government documents.

As forests have an important role in capturing and storing carbon, the LVM managed forests carbon exchange was compared with its forest management activities within one year. Latvian State Forest Research Institute "Silava" Excel spread sheets were used to estimate carbon sinks in living biomass, soil and emissions from logging, soil and fires using the methodology of the greenhouse gas accounting in the Land Use, Land Use Change and Forestry sector.

\section{RESULTS}

During the last three years, the amount of the use of resources has increased in LVM, despite the fact that the cut 
volume had decreased to 0.2 million $\mathrm{m}^{3}$ in 2011 , which can be explained with the production volume increase in the Seeds and Plants unit. The amount of $\mathrm{CO}_{2}$ emissions were $5747 \mathrm{CO}_{2}$ tonnes in 2009, $6064 \mathrm{CO}_{2}$ tonnes in 2010, but in $2011-6468$ $\mathrm{CO}_{2}$ tonnes.

The greatest resource consumption in $\mathrm{CO}_{2}$ equivalents in the company in 2011 was for diesel - 59\%, gasoline - 33\%, but less for electricity $4 \%$ and gas consumption - 4\%. LVM is increasing the proportion of renewable resources which the company uses for daily maintenance -- in 2010 it was $6 \%$, but in 2011 it was already $16 \%$.

Using Latvian State Forest Research Institute "Silava" Excel spread sheets, the carbon savings increase in the living biomass was calculated as 13 million tonnes $\mathrm{CO}_{2}$ equivalents in LVM managed forests. While emissions from logging (carbon loses in the living biomass) is 7.6 million tonnes $\mathrm{CO}_{2}$ equivalents. On this background $\mathrm{CO}_{2}$ emissions from LVM production processes are 0.1 million tonnes $\mathrm{CO}_{2}$ equivalents using outsourcing in the company product production (see Fig. 3.), but LVM company's emissions are very small. The emissions from outsourcing providers are $1 \%$ from the carbon savings in the living biomass, $2 \%$ from emissions as a result of logging or $3 \%$ from total carbon balance - emissions and removals from the forest which is $5267 \mathrm{GgCO}_{2}(1 \mathrm{Gg}$ is $1000000 \mathrm{~kg} \mathrm{CO}_{2}$ ) equivalents.

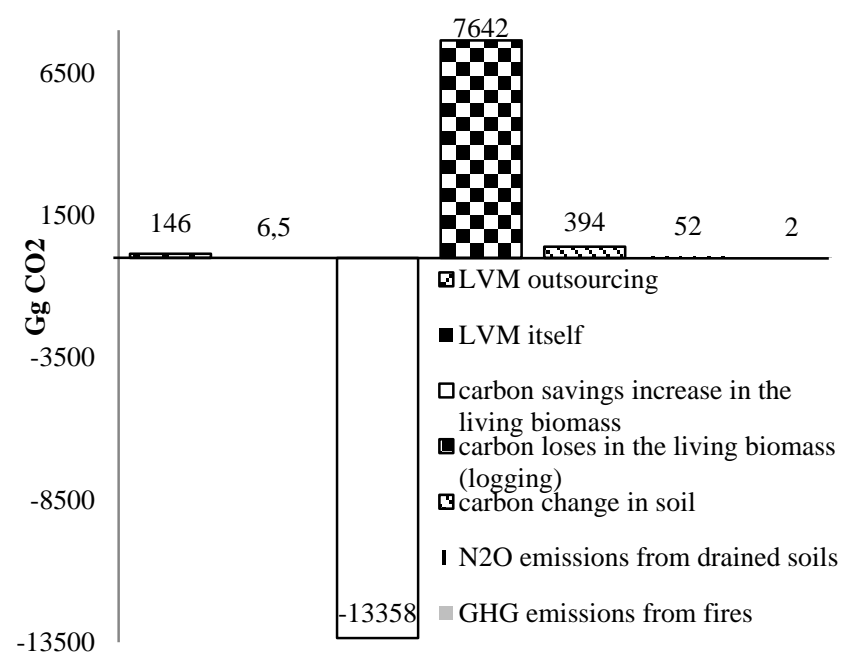

Fig.3. Emissions from LVM forests and forest management in 2011

In accordance with the Kyoto Protocol [6], Latvia's national inventory reports emissions from fuel uses in the amount of $3222 \mathrm{Gg} \mathrm{CO}_{2}$ in 2010. The emissions from LVM's outsourcing providers, which are mainly fuel consumption, in the total amount of Latvia's fuel emissions is $5 \%$ or $146 \mathrm{Gg}$ $\mathrm{CO}_{2}$.

In 2011 the analysis of LVM's outsourcing emissions showed that the largest amount of $\mathrm{CO}_{2}$ emissions in production processes are for (see Fig. 4)

- Forest infrastructure development $(47.98 \mathrm{Gg})$;

- Supply of wood assortment $(46.61 \mathrm{Gg})$;

- Roundwood harvesting $(41.81 \mathrm{Gg})$.
This could be explained due to the high amount of machinery use in these business sectors. While the Silviculture unit has only $3 \%$ emissions due to the work which is conducted by hand in this unit, but Supply of fuel chips unit has only $2 \%$ emissions due to small production amounts (obtained just in $20 \%$ from total felling area) and effective logistic.

In the Swedish study [7], energy use calculated in seedling production, silviculture, logging and timber transportation were $150-200 \mathrm{MJ} / \mathrm{m}^{3}$ of timber depending on the locality. Timber transportation gives an energy use of $113-77 \mathrm{MJ}$, silviculture 16-3MJ, seedling production 9-5MJ, logging 66$57 \mathrm{MJ}$ (cutting operations and forwarding). All LVM fuel consumption amount in litres were converted in MJ for year 2011, timber transportation gives an energy use of $110 \mathrm{MJ}$, silviculture 5MJ, seedling production $3 \mathrm{MJ}$, logging $89 \mathrm{MJ}$ (cutting operations and forwarding) at the felling volume $5741500 \mathrm{~m}^{3}$ per year. It brings together $207 \mathrm{MJ}$, which is similar to the result of the calculations presented in the Swedish study. LVM has less emission from seedling production, silviculture compared with Swedish results, but more for logging and timber transportation. This could be explained due to which exists between these two countries in forwarding distance, worse road surface/foundation, curvature and smaller road density.

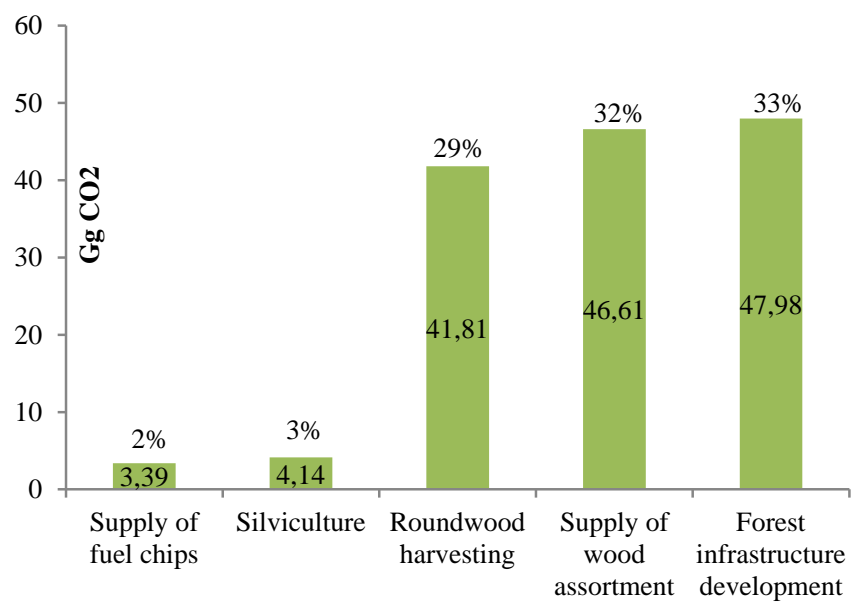

Fig. 4. LVM's outsourcing emissions in forest management in 2011.

One average tree in LVM stands is $0.26 \mathrm{~m}^{3}$ which corresponds to 0.34 tonnes $\mathrm{CO}_{2}$ equivalents respectively $1 \mathrm{~m}^{3}$ is $1300 \mathrm{~kg} \mathrm{CO}_{2}$ e equivalents. Forests absorb carbon dioxide, and thus the $\mathrm{CO}_{2}$ footprint for $1 \mathrm{~m}^{3}$ of round wood is negative throughout the production cycle. One $\mathrm{m}^{3}$ of round wood reduces $\mathrm{CO}_{2}$ by $-1273 \mathrm{CO}_{2} \mathrm{~kg}$ in 2011 (see Fig. 5). In a study about greenhouse gases storage and emission for company J.D. Irving, Limited in Northeast North America, it was determined that $22 \mathrm{~kg}$ of $\mathrm{CO}_{2} \mathrm{e}$ were emitted per $1 \mathrm{~m}^{3}$ of wood delivered to the mill gate (harvesting, transporting) [7]. While In LVM, however, for similar activities $16.2 \mathrm{~kg}$ of $\mathrm{CO}_{2} \mathrm{e}$ were emitted per $1 \mathrm{~m}^{3}$ of wood. Difference in results could be due to transportation distances. 


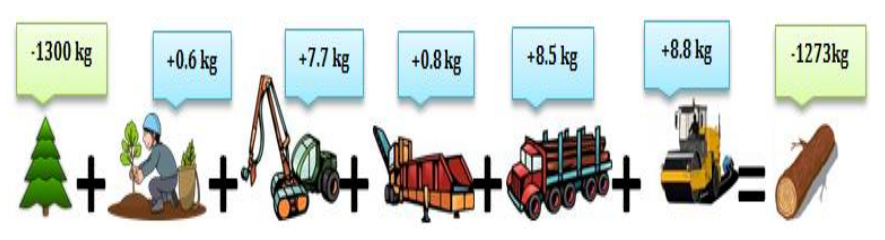

Fig. 5. The $\mathrm{CO}_{2}$ footprint for $1 \mathrm{~m}^{3}$ of round wood from LVM managed forests and outsourcing emissions in forest management in 2011.

Analysing LVM company's $\mathrm{CO}_{2}$ emissions of production processes, the largest amount of $\mathrm{CO}_{2}$ emissions are produced by the Forest Management unit and the second-largest - by the Seeds and Plants unit (see Fig. 6). Forest management is the core LVM business, and the Seeds and Plants unit implements seed and plant growing with its own resources, without using outsourcing services. Within the Forest Management unit, roundwood harvesting and silviculture produce the highest $\mathrm{CO}_{2}$ emissions, which can be explained with the intense use of cars for administration purposes to control the processes in the forest.

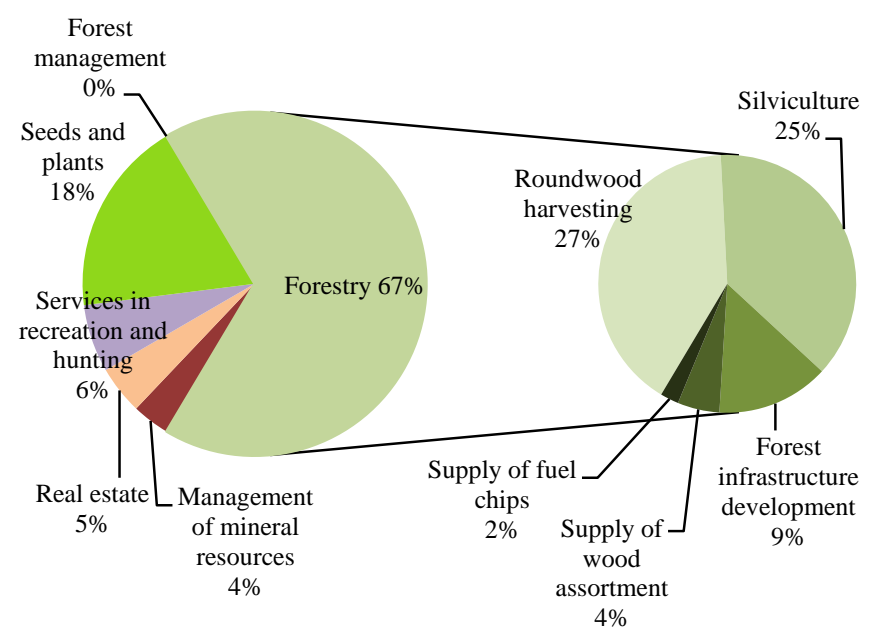

Fig. 6. LVM's own emissions in 2011

The main $\mathrm{CO}_{2}$ emission source is fuel in forest management and thus activities to reduce fuel consumption reduction should be introduced in that unit. This could accomplished through the optimization of transportation distances and use of machinery with lower fuel consumption levels. Such activities would save money, consumption of resource and reduce the negative impact on the environment

\section{IV.CONCLUSIONS}

The increase of carbon storage in living biomass is 13 million $\mathrm{CO} 2$ eq. in LVM managed forests, while the emissions from LVM management is 0.1 million tonnes of $\mathrm{CO} 2$ eq. or $1 \%$ of the increase in carbon storage in living biomass.

The emissions created by LVM itself are $6.5 \mathrm{Gg} \mathrm{CO} 2$, but the emissions from outsourcing providers in production processes are $146 \mathrm{Gg} \mathrm{CO} 2$ in 2011.
The $\mathrm{CO}_{2}$ emissions for $1 \mathrm{~m}^{3}$ of harvested round wood from LVM itself is $1 \mathrm{~kg} \mathrm{CO}$, but the emissions from outsourcing providers in production processes is $26 \mathrm{~kg} \mathrm{CO}_{2}$ in 2011 .

The largest amount of LVM's outsourcing $\mathrm{CO}_{2}$ emissions in production processes are for forest infrastructure development $(47.98 \mathrm{Gg})$, supply of wood assortment $(46.61 \mathrm{Gg})$ and roundwood harvesting $(41.81 \mathrm{Gg})$ in 2011 .

The major amount of LVM company's $\mathrm{CO}_{2}$ emissions is in the forest management unit $\left(3.6 \mathrm{Gg} \mathrm{CO}_{2}\right)$ and in the Seeds and Plants unit $\left(1 \mathrm{Gg} \mathrm{CO}_{2}\right)$ in 2011.

The greatest resource consumption in $\mathrm{CO}_{2}$ equivalents was for diesel- 59\%, gasoline -33\% in LVM in 2011.

Emissions by scope are as follows: Scope 1: 5973 tonnes of $\mathrm{CO}_{2} \mathrm{e}$, Scope 2: 470 tonnes of $\mathrm{CO}_{2} \mathrm{e}$, Scope 3: 145952 tonnes of $\mathrm{CO}_{2} \mathrm{e}$.

\section{REFERENCES}

1. David J. Nowak, Eric J. Greenfield, Robert E. Hoehn, Elizabeth Lapoint, Carbon storage and sequestration by trees in urban and community areas of the United States, Environmental Pollution, Volume 178, 2013, p 229-236 http://dx.doi.org/10.1016/j.envpol.2013.03.019

2. Kathryn R. Kirby, Catherine Potvin, Variation in carbon storage among tree species: Implications for the management of a small-scale carbon sink project, Forest Ecology and Management, Volume 246, Issues 2-3, 31 2007, p 208-221

3. Ellison D.,Lundblad M., Petersson H., Carbon accounting and the climate politics of forestry, Environmental Science \& Policy, Volume 14 $\begin{array}{lllll}\text { Issue } & 8, & 2011, & \mathrm{p} & 1062-1078\end{array}$ http://dx.doi.org/10.1016/j.envsci.2011.07.001

4. Wiedmann, T., Minx. J. A Definition of 'Carbon Footprint'. In: C. C. Pertsova, Ecological Economics Research Trends: 2008, Chapter 1, p.111. Nova Science Publishers, Inc, Hauppauge NY, USA

5. World Resources Institute and World Business Council for Sustainable Development (WRI/ WBCSD). The Greenhouse Gas Protocol: A Corporate Accounting and Reporting Standard. 2004, WRI/ WBCSD.

6. Latvia's national inventory report 1990 -2010, Submission under UNFCCC and the Kyoto Protocol, Common Reporting Formats, 2012

7. Berg S., Lindholm E. Energy use and environmental impacts of forest operations in Sweden. Journal of Cleaner production, 2005, vol. 13, p. 33-42. http://dx.doi.org/10.1016/j.jclepro.2003.09.015

8. Cameron, R. E., Hennigar, C. R., MacLean, D. A., Adams, G. W. Erdle, T. A. A Comprehensive Greenhouse Gas Balance for a Forest Company Operating in Northeast North America. Journal of Forestry, 2013, Vol. 111 (3), p. 194-205. http://dx.doi.org/10.5849/jof.12-043

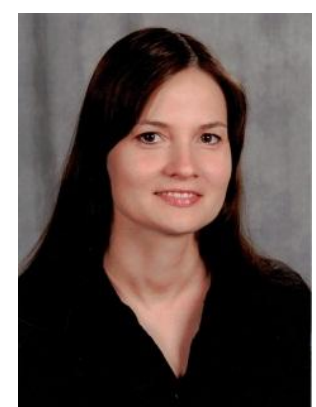

Evija Gregee-Staltmane, Dr.silv. in Forest Economic and Policy. Dr. Evija Greg̀eStaltmane has extensive work experience in the forestry sector combining this with receiving a doctor degree in Forest Economic and Policy (2011) and M. Sc. in Management (2004).

At the moment Evija uses her knowledge working for one of the leading forest management companies JSC "Latvijas valsts meži" in Latvia as a Development Project Manager. Her main focus is Forest Investments and Carbon footprint related topics.

Evija Grege-Staltmane was awarded in the contest for young scientists for contribution to scientific researches in rural development organized by Latvia Academy of Agricultural and Forestry Sciences, Latvia University of Agriculture and JSC 'Mortgage and Land Bank of Latvia' in April 29, 2011.

Address: Kristapa Street 30, Riga, LV-1046, Latvia.

E-mail: e.grege-staltmane@1vm.lv 